\title{
Cervical spine fracture associated with ankylosing spondylitis
}

Figure Cervical spine fracture
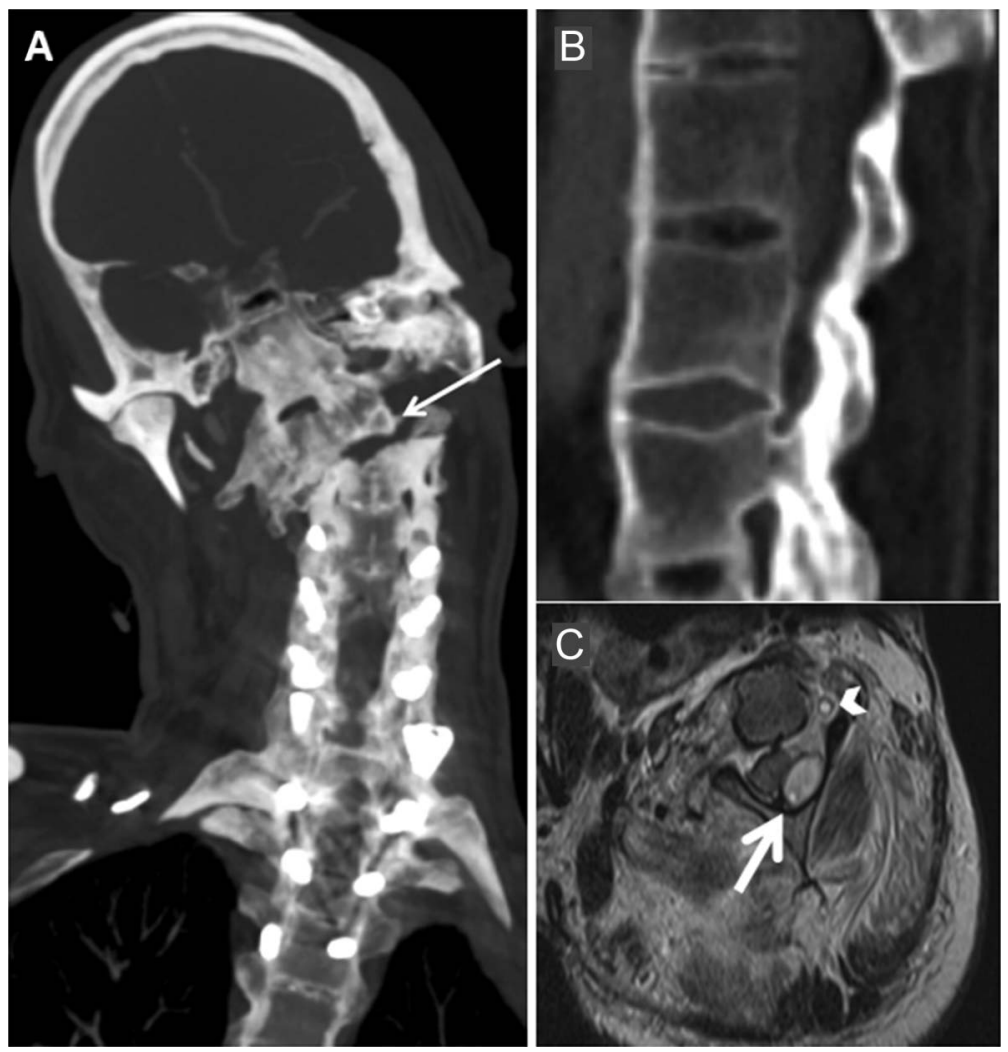

Coronal CT images show fracture through body of C2 (A, arrow) with 2.1-cm lateral displacement. Diffuse ligamentous fusion of the lumbosacral spine (B) was noted on sagittal CT images. Axial T2-weighted MRI (C) shows epidural hematoma at the $\mathrm{C} 2$ level (arrow) and thrombus in the left vertebral artery (arrowhead).

A 53-year-old man with ankylosing spondylitis (AS) was found unresponsive on the ground. He was comatose and quadriplegic with absent cough and gag reflexes but preserved corneal and pupillary responses. CT of the spine (figure) showed displaced C2 fracture, severely deformed spinal cord, and complete spinal ankylosis. He developed hemodynamic instability with persistently poor arousal, and his family elected to withdraw care. AS, chronic inflammatory disease of the axial skeleton, results in ossified ligaments and loss of elasticity, predisposing to spinal fractures following minor trauma. Three-quarters of these fractures occur in the cervical spine, with associated mortality rate of $35 \%{ }^{1}$

\section{Shamik Bhattacharyya, MD, Minjee Kim, $M D$}

From Brigham and Women's Hospital, Massachusetts General Hospital, and Harvard Medical School, Boston, MA.

Study funding: No targeted funding reported.

Disclosure: The authors report no disclosures relevant to the manuscript. Go to Neurology.org for full disclosures.

Correspondence to Dr. Bhattacharyya: sbhattacharyya3@partners.org

1. Broom MJ, Raycroft JF. Complications of fractures of the cervical spine in ankylosing spondylitis. Spine 1988;13:763-766. 


\section{Neurology}

\section{Cervical spine fracture associated with ankylosing spondylitis \\ Shamik Bhattacharyya and Minjee Kim \\ Neurology 2014;83;1297 \\ DOI 10.1212/WNL.0000000000000833}

This information is current as of September 29, 2014

\section{Updated Information \& Services}

References

Subspecialty Collections

Permissions \& Licensing

Reprints including high resolution figures, can be found at: http://n.neurology.org/content/83/14/1297.full

This article cites 1 articles, 0 of which you can access for free at: http://n.neurology.org/content/83/14/1297.full\#ref-list-1

This article, along with others on similar topics, appears in the following collection(s):

All Immunology

http://n.neurology.org/cgi/collection/all_immunology All Spinal Cord

http://n.neurology.org/cgi/collection/all_spinal_cord

Coma

http://n.neurology.org/cgi/collection/coma

Critical care

http://n.neurology.org/cgi/collection/critical_care

Spinal cord trauma

http://n.neurology.org/cgi/collection/spinal_cord_trauma

Information about reproducing this article in parts (figures,tables) or in its entirety can be found online at:

http://www.neurology.org/about/about_the_journal\#permissions

Information about ordering reprints can be found online:

http://n.neurology.org/subscribers/advertise

Neurology ${ }^{\circledR}$ is the official journal of the American Academy of Neurology. Published continuously since 1951, it is now a weekly with 48 issues per year. Copyright @ 2014 American Academy of Neurology. All rights reserved. Print ISSN: 0028-3878. Online ISSN: 1526-632X.

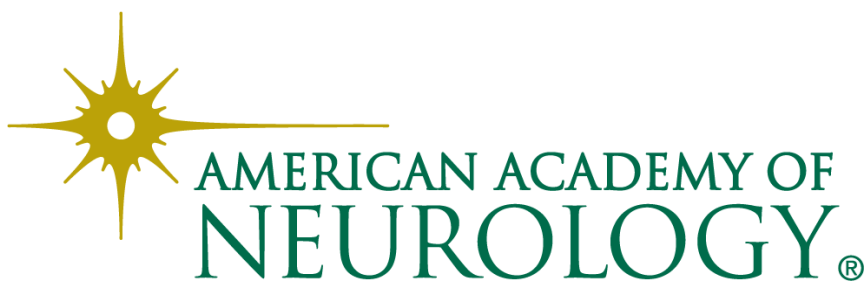

